\title{
Anti-Mycobacterial Peptides: From Human to Phage
}

\author{
Tieshan Tenga,b Jiafa Liu ${ }^{\mathrm{c}}$ Hongping Wei ${ }^{\mathrm{a}}$ \\ aKey Laboratory of Special Pathogens and Biosafety, Wuhan Institute of Virology, Chinese Academy \\ of Sciences, Wuhan, bUniversity of Chinese Academy of Sciences, Beijing, 'Hubei Center for Disease \\ Control and Prevention, Wuhan, China
}

\author{
Key Word \\ Anti-mycobacterial peptides • Mycobacterial • Tuberculosis
}

\begin{abstract}
Mycobacterium tuberculosis is the major pathogen of tuberculosis (TB). With the growing problem of $M$. tuberculosis resistant to conventional antibiotics, especially multi-drug resistant tuberculosis (MDR-TB) and extensively-drug resistant tuberculosis (XDR-TB), the need for new TB drugs is now more prominent than ever. Among the promising candidates for anti-TB drugs, anti-mycobacterial peptides have a few advantages, such as low immunogenicity, selective affinity to prokaryotic negatively charged cell envelopes, and diverse modes of action. In this review, we summarize the recent progress in the anti-mycobacterial peptides, highlighting the sources, effectiveness and bactericidal mechanisms of these antimicrobial peptides. Most of the current anti-mycobacterial peptides are derived either from host immune cells, bacterial extraction, or mycobacteriophages. Besides trans-membrane pore formation, which is considered to be the common bactericidal mechanism, many of the anti-mycobacterial peptides have the second non-membrane targets within mycobacteria. Additionally, some antimicrobial peptides play critical roles in innate immunity. However, a few obstacles, such as short half-life in vivo and resistance to antimicrobial peptides, need overcoming before clinical applications. Nevertheless, the multiple functions of anti-mycobacterial peptides, especially direct killing of pathogens and immune-modulators in infectious and inflammatory conditions, indicate that they are promising candidates for future drug development.
\end{abstract}

\section{Introduction}

Copyright $\odot 2015$ S. Karger AG, Basel

Recent statistics from the World Health Organization (WHO) estimate that one-third of the world's population is latently infected with M. tuberculosis, and from this pool, there are 9 million cases of active tuberculosis, resulting in 2-3 million deaths every year. Multi-drug 
resistant tuberculosis (MDR-TB), extensively-drug resistant tuberculosis (XDR-TB) and coinfection with human immunodeficiency virus (HIV) are the causes of driving the increase in incidence and death. Except the novel anti-TB drug bedaquiline approved in 2012, no novel drugs have been marketed for TB in the past 40 years [1]. To counteract the emerging MDRTB threats, identification and development of novel fast-acting and affordable compounds for TB treatment is now more prominent than ever.

Antimicrobial peptides are gene-encoded peptides produced by genera from all domains, showing direct activity against a wide range of microorganisms and playing major roles in host defense [2]. Some features of antimicrobial peptides, such as low immunogenicity, selective affinity to prokaryotic negatively charged cell envelopes, and diverse modes of action make anti-mycobacterial peptides promising anti-TB therapeutics [3]. In this review, we summarize the anti-mycobacterial peptides derived from different sources, including host immune cells, bacterial extraction, mycobacteriophages, as well as synthetic peptides (Table 1).

\section{Human immune cells-derived anti-mycobacterial peptides}

During mycobacterial infections, antimicrobial peptides, such as cathelicidins, defensins, and granulysins, are produced in innate immune cells. These peptides are also important signaling molecules in regulation of both innate and adaptive immunity, exhibiting immunomodulatory functions in host defense.

\section{$L L-37$}

LL-37 peptide is derived from Human Cationic Antimicrobial Protein 18 (hCAP18), which consists of a highly conserved $\mathrm{N}$-terminal signal domain and a structurally variable cationic antimicrobial domain at the C-terminal [4]. hCAP18 is synthesized in activated neutrophils and epithelial cells, then released into extracellular milieu [5]. After that, hCAP18 is cleaved by proteinase-3 to form biologically active LL-37 peptide, which is the C-terminal of hCAP18 and then taken up by neutrophils [6]. The expression of hCAP18 was induced by 1, 25-dihydroxyvitamin D3 (1,25D3), which also induced the co-localization of mycobacterial phagosomes with autophagosomes in human macrophages through a cathelicidin-dependent manner [7].

The exogenous addition of LL-37 or endogenous over-expression of LL-37 in macrophages significantly reduces the intracellular survival of $M$. tuberculosis. After incubation of macrophages infected by M. tuberculosis $\mathrm{H} 37 \mathrm{Rv}$ and M. bovis BCG with LL-37, more than $60 \%$ of both strains could be killed [8]. At the same time, no cytotoxic effects on macrophages were observed. The above results indicated that LL-37 exhibited anti-mycobacterial activity in vitro as well as inside macrophages. LL-37 also plays an important role in the innate immune response against $M$. tuberculosis. It functioned as an immune-regulatory agent through the activation of multiple receptors, such as a $\mathrm{G}$ proteincoupled receptor N-formylpeptide receptor-like-1 (FPRL-1) [9]. FPRL-1 can induce the secretion of chemokines including IL-8 and MCP-1 to chemically attract human peripheral blood neutrophils, monocytes, and T cells to the injury site [10].The mechanism of LL-37 against M. tuberculosis in vitro is pore formation or membrane barrier disruption. While in vivo, LL-37 involves in both Toll-like receptor (TLR) activation of monocytes to induce the killing of M. tuberculosis and vitamin-D mediated human antimicrobial responses against M. tuberculosis. Furthermore, LL-37 could potently reverse the ability of lipopolysaccharide (LPS) to stimulate the production of pro-inflammatory cytokines, such as TNF- $\alpha$ [11].

Two derivative peptides of LL-37 with higher anti-mycobacterial activity have been synthesized [12, 13]. One derivative peptide is a truncated variant of LL-37 named as LLKKK-18, in which the polar uncharged residues glutamine (Q22), asparagine (N30) and negatively charged aspartic acid (D26) are substituted by positively charged lysine [8]. LLKKK-18 was found to be more active against M. tuberculosis compared with LL-37, and no 
cytotoxic effects on macrophages. LLKKK18 also showed increased killing of M. tuberculosis in combination with the biogenic-silver nanoparticles [14]. The other derivative peptide is the D-enantiomer of LL-37 named as D5, in which three alanine residues are substituted with more hydrophobic leucine residues, and valine at position 16 is substituted with lysine for avoiding the high level of self-association [12]. The minimum inhibitory concentration (MIC) values of D5 against $M$. tuberculosis were $35.2 \mu \mathrm{g} / \mathrm{ml}$ and $49 \mu \mathrm{g} / \mathrm{ml}$ against the MDRTB strain [12]. D5 also showed a significantly better hemolytic activity and therapeutic index value than the parent LL-37 peptide. The higher activity of D5 could be due to that D-enantiomer has better action of membrane-disrupting $[15,16]$ and bacterial biofilm disassembly [17].

In addition to its direct anti-mycobacterial activity, LL-37 also possesses antifungal and anti-viral activity [18]. Moreover, it is capable of inducing wound healing [19], angiogenesis and modulating apoptosis [20]. The cathelicidin peptide was also found able to suppress tumor growth [21]. All these studies suggested that LL-37 peptide would have enormous potential to be a therapeutic agent not only for the treatment of mycobacterial infections.

\section{Human defensins}

The defensins belong to the family of small antimicrobial peptides having six highly conserved cysteine residues, resulting in three disulfide linkages. According to the structural differences of the mammalian defensins, they can be divided into three main subfamilies: $\alpha$-defensins, $\beta$-defensins and the recently described $\theta$-defensins. The defensins are key components of the innate immune response in phagocytic cells against intracellular pathogens, such as M. tuberculosis, by an oxygen-independent mechanism [22].

Human neutrophil peptide 1 (HNP-1) is one of the $\alpha$-defensins present in the azurophilic granules of polymorphonuclear neutrophils. In vitro studies showed that HNP-1 was active against M. tuberculosis H37Rv in a concentration-dependent manner. The MIC value of HNP1 against $M$. tuberculosis $\mathrm{H} 37 \mathrm{Rv}$ was $2.5 \mu \mathrm{g} / \mathrm{ml}$, which was higher than that of isoniazid $(0.3$ $\mu \mathrm{g} / \mathrm{ml})$ and rifampicin $(0.2 \mu \mathrm{g} / \mathrm{ml})$. However, HNP-1 had been shown to have synergistic activity in combination with the first-line anti-TB drugs. The combination of HNP-1 with either isoniazid or rifampicin could reduce the MICs of isoniazid and rifampicin against M. tuberculosis H37Rv to 0.0375 and $0.025 \mu \mathrm{g} / \mathrm{ml}$, respectively [23]. In a mouse model, combination with low dosage of isoniazid and rifampicin, HNP-1 resulted in significantly better clearance of $M$. tuberculosis H37Rv than the same dose of drugs alone [24]. Transmission electron microscopy suggested that HNP-1 killed M. tuberculosis H37Ra mainly by binding to the plasma membrane, followed by permeabilization. DNA was suggested to be the intracellular secondary target for HNP-1 [25], which resulted in general inhibition in the macromolecular biosynthesis, with maximum inhibition for lipid biosynthesis [26]. HNP-1 also plays an important role in the pulmonary innate host defense system during mycobacterium infection, such that HNP-1 can mediate macrophages to secret TNF-a, which stimulates neutrophil mycobactericidal activity, and recruits monocytes to the infection site $[27,28]$.

There are four different human $\beta$-defensin (HBD1-4) that are expressed in both leukocytes and epithelial cells [29]. All $\beta$-defensins are expressed inducibly, except HBD-1, which is expressed constitutively. HBD-2 is an antimicrobial peptide that plays an important role in innate immunity. It is well known that HBD-2 is associated with intracellular $M$. tuberculosis lysis [30]. Furthermore, in vitro studies indicated that HBD-2 could suppress $M$. tuberculosis growth. In combination with first-line anti-TB drugs isoniazid and rifampicin, HBD-2 could reduce M. tuberculosis load significantly. A study by Kisich et al. [31] showed that $M$. tuberculosis could be killed in human monocyte derived macrophages transfected with HBD-2 gene , implicating that HBD-2 plays a role in immunity against $M$. tuberculosis. In a mouse model, it was found that $\beta$-defensins induced by L-isoleucine showed improved therapeutic efficiency to TB [32]. It was also found that HBD-2 expression was significant higher in latent infection than in progressive infection, suggesting that HBD-2 could be used as a biomarker for re-activation [33]. 
It has been proposed that human defensins act on microbial membranes and form membrane pores, which are the mechanism for their antimicrobial activity. Besides this, defensins are broad-spectrum antimicrobial agents capable of anti-viral, anti-fungal, and having immune- modulatory and chemokines activity. However, before using defensins therapeutically, we must pay attention to some concerns. First, defensins showed a nonspecific cytotoxicity to normal and malignant mammalian cells [34]. Second, the genome of $M$. tuberculosis contains a gene $m p r F$, which was found associated with resistance to several antimicrobial peptides including defensins [35].

\section{Granulysin}

Granulysin is a member of the saposin-like protein family, and has highly homologous to NK-lysin. Granulysin contains four helical bundle motifs, with the helices enriched with positively charged arginine and lysine residues. Granulysin is a cationic small glycoprotein, synthesized as a secretory $15 \mathrm{kDa}$ precursor. Then the precursor is enzymatically processed into a granular $9 \mathrm{kDa}$ protein, which is cytolytic against extracellular and intracellular $M$. tuberculosis [36]. Granulysin localizes in human CTL and NK cell granules and is the only antimicrobial peptide identified in CTL cells, in which both $15 \mathrm{kDa}(15 \mathrm{~K})$ precursor and $9 \mathrm{kDa}$ (9K) granulysin could be detected [37].

The $15 \mathrm{~K}$ granulysin could enter into human macrophages and kill $M$. tuberculosis in the cytoplasm of macrophages. Recombinant $15 \mathrm{~K}$ granulysin contributed directly to immune defense against TB, resulted in decreased number of bacilli in the lungs of the mice infected with M. tuberculosis by aerosol challenge [38]. Granulysin as candidate immune marker for TB was also investigated during childhood and adolescence. Compared with controls, the results indicated that granulysin remained high in individuals newly diagnosed with active TB or latent TB infection [39].

Two granulysin-derived peptides granF2 [40] and G13 [41] were found having a particularly high activity against clinical isolates of both drug-susceptible $M$. tuberculosis and MDR-TB. More importantly, the bactericidal activity against MDR-TB was better than that against drug susceptible strains. GranF2 showed a significant synergistic effect with ethambutol against susceptible clinical isolates. Although both of them have an anti-TB effect through permeating the cell wall, GranF2 and ethambutol act at different sites of the $M$. tuberculosis cell wall. In combination with streptolysin $\mathrm{O}$, granF2 could efficiently reduce the growth of MDR-TB, which can survive and persist within macrophages [42]. It was believed that streptolysin gained access to and killed the intracellular bacteria after destructing the host cell walls by GranF2.

It has been reported that acting on mycobacterial membranes, disrupting synthetic liposomes and inducing apoptosis of mammalian cells are the antimicrobial mechanisms for granulysins. Granulysins also have potent broad-spectrum antimicrobial activity against bacteria, fungi, and tumor cell. Granulysins containing either helix2 or helix3 can lyse bacteria, while only granulysins containing helix3 can lyse tumor. Both intra- and intermolecular disulfide bonds are necessary for the peptides to lyse tumor targets, whereas lysis of bacteria is unaffected by reduction of the disulfide bonds.

\section{From human non-immune cells}

Different types of human non-immune cells, such as liver hepatocytes, keratinocytes and eosinophils, can also produce antimicrobial peptides including ubiquitin-derived peptides, hepcidin and RNase-derived peptides. These peptides exert antimycobacterial effects through direct killing activities, but without immuno-modulatory activities.

Lysosomal ubiquitin-derived peptides

Ubiquitin (Ub) is a post translational modification protein and usually acts as a signal for proteasome degradation and endocytosis. However, some studies showed that ubiquitin- 
derived peptides located in the lysosome contribute to anti-mycobacterial activity [43].

When macrophages are activated by mycobacterial infection, mycobacteria are delivered to the lysosome and to be killed through both oxidative and non-oxidative mechanisms. Oxidative mechanisms include the action of reactive oxygen and nitrogen intermediates on bacteria. Non-oxidative mechanisms are linked to the ubiquitin-derived peptides. Although ubiquitin exists in the lysosome, which contains some other proteases with direct antimycobacterium activity, the intact ubiquitin itself has no bactericidal activity to mycobacteria in vitro. Autophagy plays a key role for the mycobactericidal activity of ubiquitin-peptides, because it can promote the fusion of $M$. tuberculosis-containing phagosome with lysosome, and then enhance the delivery of ubiquitin to lysosome [44]. Ubiquitin also has been used as a vaccine component. Fusing to mycobacterium antigens, such as ESAT-6 [45], Ag85A [46] and MPT64 [47], could significantly increase the efficacy of the vaccines against TB.

Ub2 is a ubiquitin-derived peptide, which was identified in lysosome by Kieffer et al. [48], exerted significant antibacterial activity against $M$. Tuberculosis with a MIC of $5 \mu \mathrm{M}$ [44]. It has been shown that the secondary structure $\beta$-sheet of Ub2 was vital to its membrane targeting ability and mycobactericidal activity [49]. Point mutations showed that the crucial residues of $\mathrm{Ub} 2$ for bactericidal activity were charged residues positioned at the $\mathrm{C}$-terminal end of the peptide. Some mutants such as Ub2H4A, Ub2R8A, Ub2R10A, Ub2G11A, and Ub2G12A would significantly reduce the net charge of the peptide and decreased their mycobactericidal activity [49], though the point-mutated peptides retained the same membrane targeting capacity. The mycobactericidal mechanism of Ub2 was associated with its outer membrane permeability [50]. Subcellular localization studies showed that Ub2 not only inserted into the bacterial membrane but also reached the cytoplasm. Loss of membrane integrity in lysosome environments exposed the bacterium to adverse conditions, including additional bactericidal molecules. Incorporation of Ub2 into the bacterial membrane was explained using a micellar aggregate channel model, in which a peptide at high local concentrations induced the cytoplasmic membrane to form micellar-like structures that effectively generated channels in the membrane [50]. Ub2 exhibited the greatest bactericidal activity at pH 5.5 and $\mathrm{pH}$ 6, which was in line with the $\mathrm{pH}$ values of mature mycobacteria-containing phagosomes.

In addition to Ub2, Cathepsin cleavage of ubiquitin proteins generates other peptides, such as Ub17.1 and Ub21, which have $\alpha$-helical secondary structures with lower net charges than Ub2. However, both of them could not disrupt the mycobacterial membrane and had little mycobactericidal activity. Moreover, a transcriptional regulator msmeg_0166 located in M. smegmatis genome, was found able to lead to the resistance of mycobacteria to Ub2 [51].

\section{Hepcidin}

Hepcidin is a key regulator of iron recycling by inhibiting iron absorption in response to iron overload and flammatory stimuli [52]. The precursor is synthesized in macrophages and liver hepatocytes possessing 84 residues, but then cleaved to yield the mature 25 residues hepcidin and 35 residues proregion. Both of them have antibacterial activity against mycobacteria.

M. tuberculosis and its bacterial constituent, such as lipoarabinomannan and culture filtrate proteins, could strongly induce hepcidin mRNA expression in human alveolar epithelial cells and dendritic cells [53]. The production of hepcidin by cells present in the lungs supports the importance of hepcidin in innate host defense against $M$. tuberculosis infection. Iron is essential for the growth and the survival of mycobacteria. During infection, both host macrophage and the pathogen compete for iron. And then hepcidin will be secreted by macrophage as a key role in restricting the growth of mycobacteria though inhibiting release of the recycled iron by macrophages.

In vitro, hepcidin could inhibit M. tuberculosis growth and caused structural damage to the mycobacteria [54]. After incubation with hepcidin, the colony form units (CFUs) of $M$. tuberculosis were reduced by $50 \%$ compared with that of the control. Transmission electron microscopy (TEM) revealed that hepcidin could lead to structural damages to the mycobacteria. A qRT-PCR study [55] found that Hepcidin mRNA could be induced by 
mycobacteria and IFN- $\gamma$ in macrophages, but not pro-inflammatory cytokines or iron overload. Hepcidin expression was also found regulated by TLR2 and TLR4 receptors in macrophages via the MyD88-dependent signaling pathway [56]. These findings provided clues to understand the roles of Hepcidin in host defense strategies against mycobacterial infections.

Human host defense ribonucleases (RNase)

RNase 3 and RNase 7 are the representative members of the vertebrate RNase superfamily secreted by innate cells, such as stimulated keratinocytes and eosinophils, which are potent host defense effector cells activated by mycobacterial infection. Both RNase 3 and RNase 7 are small cationic proteins with a well characterized cytotoxic action contributing to the host defense against mycobacterial infections.

RNase 3 is secreted by eosinophil secondary granules and also called the eosinophil cationic protein (ECP). RNase 7 is abundantly secreted by keratinocytes and mainly involved in the skin defense against infective microorganisms, like M. leprae. RNase 3 and RNase 7 inhibited mycobacterial growth in micromolar range and the MIC values against M. tuberculosis were $20 \mu \mathrm{M}$. The first 45 residues of the N-terminal of RNase (RN3(1-45) or RN7(1-45)), encompassing three $\alpha$-helices, retain most anti-M. vaccae activity of the full protein. The RN7(1-45) peptide showed similar MIC value and cell viability to the parental RNase 7 [57]. While, the peptide RN3 (1-45) has better antimicrobial activity than the parental protein. The MIC value of RN3 (1-45) was below $10 \mu \mathrm{M}$. The better activity may be owing to a higher $\mathrm{pI}(\mathrm{pI}=12.61$ versus 10.94$)$ and more positive net charges $(+8$ versus +7 ) in RN3(1-45) than in RN7(1-45). Ultrastructural analysis showed that the envelope integrity of $M$. vaccae cells was completely disrupted after interaction with both RNases and their derived peptides.

\section{HCL2}

HCL2 is part of a seven-bundle helix of the human cytochrome c oxidase subunit3 (COX3) proteins, with a helical structure similar to an early secreted antigenic target protein ESAT-6. HCL2 can interact with culture filtrate protein 10 (CFP10) through hydrophobic interactions and disrupt ESAT-6:CFP10 complex. ESAT-6 and CFP10 proteins are secreted into the extracellular matrix during broth culture of M. tuberculosis and play critical roles in mycobacterial pathogenesis [58-60]. HCL2 could disrupt the heterodimeric interaction between ESAT- 6 and CFP10 in vivo, and significantly inhibited the growth of both extracellular and intracellular M. tuberculosis. HCL2 could strongly hinder the survival of M. tuberculosis inside human macrophagial THP-1 with no cytotoxicity. In the presence of HCL2, either endogenous or exogenous, cell wall and cell morphology of $M$. tuberculosis showed distinct degeneration by electron microscopy.

\section{Anti-mycobacterial Peptides Produced by Bacteria}

Unlike most antibiotics, which are secondary metabolites, bacteriocins are ribosomally -synthesized antimicrobial peptides produced by Gram-positive or Gram-negative bacteria. Bacteriocins can kill other closely-related or non-related microbiotas, but will not harm the bacteria themselves because of their specific immunity. Bacteriocins are unique in their large diversity of structures and functions, wide resources, and heat stability.

\section{Lacticin 3147}

Lantibiotics are antimicrobial peptides that undergo extensive posttranslational modifications, characterized by the unusual lanthionine and/or methyllanthionine residues, dehydrated serines and/or threonines [61]. Among them, lacticin 3147 produced by Lactococcus lactis had inhibitory activity against M. tuberculosis H37Ra, Mycobacterium avium and Mycobacterium kansasi, with MIC $_{90}$ values of $7.5 \mu \mathrm{g} / \mathrm{ml}, 60 \mu \mathrm{g} / \mathrm{ml}$ and $15 \mu \mathrm{g} /$ 
$\mathrm{ml}$, respectively [62]. Lacticin 3147 is a two-peptide (LtnA1 and LtnA2) lantibiotic with LtnA1 and LtnA2 at 1:1 ratio and effective at nanomolar concentrations [63, 64]. Three D-alanines present in lacticin 3147 are vital for its antimicrobial activity. The conversion of L- alanine to D-alanine in lacticin 3147 was performed by dha reductase $[65,66]$.The ability to create D-residues in lacticin 3147 may provide a novel model of designing D-amino acid-containing peptides for novel antimicrobial activities. Lacticin 3147 possesses more than one mechanism of action, inhibiting peptidoglycan synthesis as well as forming pores in the membrane of target cells $[67,68]$. Both activities were facilitated by binding to the peptidoglycan precursor, lipid II [69]. It is notable that the structure of mycobacterial lipid II differs from all other structures in bacteria investigated to date [70], which is due to an alternative synthesis pathway as well as modifications on both the $\mathrm{N}$-acetylmuramic acid and peptide side chain components.

\section{E50-52}

E50-52 was obtained from isolates of Enterococcus faecalis, and belongs to class IIa bacteriocins. E50-52 inhibited mycobacterial growth within macrophages at a non-cytotoxic concentration of $0.1 \mathrm{mg} / \mathrm{L}$, but inhibition stronger than rifampicin could be achieved at a high concentration of $1 \mu \mathrm{g} / \mathrm{ml}$ [71]. In macrophages, E50-liposome complex was able to inhibit mycobacterial growth without damaging the membrane of macrophages. In a mouse model, E50-liposome was able to significantly increase the life span of the infected animals, which were injected once every $24 \mathrm{~h}$ for 5 consecutive days. E50 may also serve as a good supplement to antibiotics in the treatment of MDR-TB [71]. Nevertheless, the efficacy against MDR-TB in mouse model of chronic TB needs testing.

Lassomycin

Lassomycin was found by screening extracts from uncultured species against M. tuberculosis [72]. Lassomycin is a cyclic peptide, synthesized and secreted by the environmental microbe Lentzea kentuckyensis. Its structure is generated by cleavage of a ribosomal product, cyclization, and C-terminal esterification. Except M. tuberculosis, lassomycin exhibits little activity against other bacteria or mammalian cells. This specificity is due to its unique target, ClpC1P1P2, which is an essential ATP-dependent protease for viability of mycobacteria [73], but not in other bacteria. Lassomycin can bind to an acidic $\mathrm{N}$-terminal pocket of ClpC1P1P2 and activate its ATPase activity, which leads to protein degradation within mycobacteria. It is unusual for an antibacterial peptide to activate rather than inhibit its target enzyme. The intriguing mechanism of action is relatively rare, showing lassomycin is a very unusual bactericidal agent. Lassomycin had a MIC of $0.8-3 \mathrm{mg} / \mathrm{ml}$ and MBC of 1-4 mg/ml against $M$. tuberculosis including MDR-TB and XDR-TB isolates [72]. Lassomycin would be a promising anti-TB drug, though its cytotoxic and anti-mycobacterial activity in animal models need to be tested.

\section{Mycobacteriophage-derived anti-mycobacterial peptides}

Bacteriophages are the viruses of their host bacteria, and viewed as potential antibacterial therapeutics [74]. Ren Lai et al. [75] tested more than 200 presumed antibacterial peptides on the basis of genomic information of mycobacteriophages. One of them, PK34 showed M. tuberculosis-killing activity with a MIC of $50 \mu \mathrm{g} / \mathrm{ml}$ in vitro, and exerted strong antimycobacterial activity in vivo. PK34 could bind to trehalose-6, 6-dimycolate (TDM), which is an important target for anti-mycobacterial agents. In a mouse model, PK34 showed significant inhibition on inflammatory cytokines secretions by inactivating MAPK and PKB signals, while maintained certain pro-inflammatory cytokine production. In addition to its direct M. tuberculosis-killing ability, PK34 might be a useful adjunct in immuno-regulation. PK34 exerted potential protective effects against $M$. tuberculosis infection by both direct $M$. tuberculosis killing and inflammation inhibition. A few peptides derived from other phages 
Table 1. The sequences and properties of anti-mycobacterial peptides.* Represent $\mathrm{MIC}_{90}$; Rare amino acids are shown in bold

\begin{tabular}{|c|c|c|c|c|c|}
\hline Name & Sequence & MIC & cytotoxicity & Test & Ref. \\
\hline LL-37 & $\begin{array}{l}\mathrm{NH}_{2-} \\
\text { LLGDFRKSKEKIGKEFKRIVQRIKDFL } \\
\text { RNLVPRTES-OH }\end{array}$ & $2.1 \mu \mathrm{g} / \mathrm{ml}$ & No & mice & $\begin{array}{l}{[6,8,12,} \\
18,103- \\
108]\end{array}$ \\
\hline LLKKK-18 & KEFKRIVKRIKKFLRKLV & $\begin{array}{l}25 \mu \mathrm{g} / \mathrm{ml} \\
*\end{array}$ & No & In vitro & {$[8,109]$} \\
\hline D5 & $\begin{array}{l}\text { Ac- } \\
\text { KWKSFLKTFKSLKKTKLHTLLKLISS- } \\
\text { amide }\end{array}$ & $\begin{array}{l}35.2 \mu \mathrm{g} / \mathrm{m} \\
\mathrm{l}\end{array}$ & No & Ex vivo & [12] \\
\hline G13 & QRSVSNAATRVCRTGRSRW & - & Yes & Ex vivo & {$[42,110]$} \\
\hline GranF2 & VCRTGRSRWRDVCRNFMRRYQSR & - & Yes & Ex vivo & {$[42,110]$} \\
\hline proregion & $\begin{array}{l}\text { SVFPQQTGQLAELQPQDRAGARASW } \\
\text { MPMFQRRRRR }\end{array}$ & - & No & Ex vivo & \\
\hline HNP-1 & $\begin{array}{l}\text { DCYCRIPACIAGERRYGTCIYQGRLWA } \\
\text { FCC }\end{array}$ & $2.5 \mu \mathrm{g} / \mathrm{ml}$ & Yes & mice & [111] \\
\hline HCL2 & $\begin{array}{l}\text { ESTYQGHHTPPVQKGLRYGIILFITSEV } \\
\text { FFFAGFF }\end{array}$ & - & No & In vitro & [112] \\
\hline MIAP & GIGKFLKSKGKFGKA & $300 \mu \mathrm{g} / \mathrm{ml}$ & No & Ex vivo & $\begin{array}{l}{[113,} \\
114]\end{array}$ \\
\hline $\mathrm{Ub} 2$ & STLHLVLRLRGG & $5 \mu \mathrm{M}$ & No & Ex vivo & $\begin{array}{l}{[44,49,} \\
115]\end{array}$ \\
\hline $\begin{array}{l}\text { RNase 3(1- } \\
45)\end{array}$ & $\begin{array}{l}\text { RPPQFTRAQWFAIQHISLMPPRCTIA } \\
\text { MRAINNYRWRCKNQNTFLR }\end{array}$ & $10 \mu \mathrm{M}$ & Yes & In vitro & [57] \\
\hline $\begin{array}{l}\text { RNase } 7(1- \\
45)\end{array}$ & $\begin{array}{l}\text { KPKGMTSSQWFKIQHMQPSPQACNS } \\
\text { AMKNINKHTKRCKDLNTFLH }\end{array}$ & $20 \mu \mathrm{M}$ & Yes & In vitro & {$[57,116]$} \\
\hline Hepcidin & DTHFPICIFCCGCCHRSKCGMCCKT & - & No & Ex vivo & $\begin{array}{l}{[55,117} \\
118]\end{array}$ \\
\hline $\begin{array}{l}\text { D-LFcin17- } \\
30\end{array}$ & FKCRRWQWRMKKLG & $\begin{array}{l}14.4 \mu \mathrm{g} / \mathrm{m} \\
\mathrm{l}^{*}\end{array}$ & No & mice & [119] \\
\hline Lassomycin & GLRRLFADQLVGRRNI- $\mathrm{CO}_{2} \mathrm{CH}_{3}$ & $0.8 \mu \mathrm{g} / \mathrm{ml}$ & - & In vitro & [72] \\
\hline Nisin A & $\begin{array}{l}\text { IDhbAIDLADhaPGAKAbuGALMGAN } \\
\text { MKAbuAAbuANASIHVDhaL }\end{array}$ & $\begin{array}{l}60 \mu \mathrm{g} / \mathrm{ml} \\
*\end{array}$ & - & In vitro & [120] \\
\hline $\begin{array}{l}\text { lacticin } \\
3147\end{array}$ & $\begin{array}{l}\text { AADhbNDhbFALADYWGNNGAWAA } \\
\text { buLAbuHEAMAWAK }\end{array}$ & $\underset{*}{7.5 \mu \mathrm{g} / \mathrm{ml}}$ & - & In vitro & $\begin{array}{l}{[62,65} \\
121,122]\end{array}$ \\
\hline E50-52 & $\begin{array}{l}\text { TTKNYGNGVCNSVNWCQCGNVWASC } \\
\text { NLATGCAAWLCKLA }\end{array}$ & $\begin{array}{l}0.1 \mu \mathrm{g} / \mathrm{ml} \\
*\end{array}$ & No & In vitro & [71] \\
\hline pK34 & $\begin{array}{l}\text { PRVIETKVHGREVTGLARNVSEENVD } \\
\text { RLAKRWIK }\end{array}$ & $50 \mu \mathrm{g} / \mathrm{ml}$ & No & Mice & [75] \\
\hline 1-C134mer & $\begin{array}{l}\text { H-Ntridec-NLys-Nspe-Nspe-NLys-NH } \\
2\end{array}$ & $6.3 \mu \mathrm{M}$ & Yes & In vitro & [123] \\
\hline $\begin{array}{l}\text { Ci-MAM- } \\
\text { A24 }\end{array}$ & $\begin{array}{l}\text { WRSLGRTLLRLSHALKPLARRSGW- } \\
\text { NH2 }\end{array}$ & - & No & Ex vivo & [124] \\
\hline
\end{tabular}

could also kill their hosts directly. Bacteriophage-derived peptidase $\mathrm{CHAP}_{\mathrm{K}}$, containing only the cysteine, histidine-dependent amidohydrolases/peptidases (CHAP) domain of endolysin LysK, possessed lytic activity against live clinical staphylococcal isolates and could eliminate staphylococcal biofilms [76, 77]. $\mathrm{PlyG}_{106-165}$ (residues 106 to 165) was found able to specifically recognize $B$. anthracis spores, through binding to the exosporium of the spores [78]. These data demonstrated that bacteriophage-derived peptides represented attractive approaches for the future design of antibacterial agents [79].

\section{Future Directions and Concluding Remarks}

As shown in Table 1 and Fig. 1, anti-mycobacterial peptides reported so far displayed considerable diversity in their primary sequences, lengths, biological activities, sources and antibacterial mechanisms. 


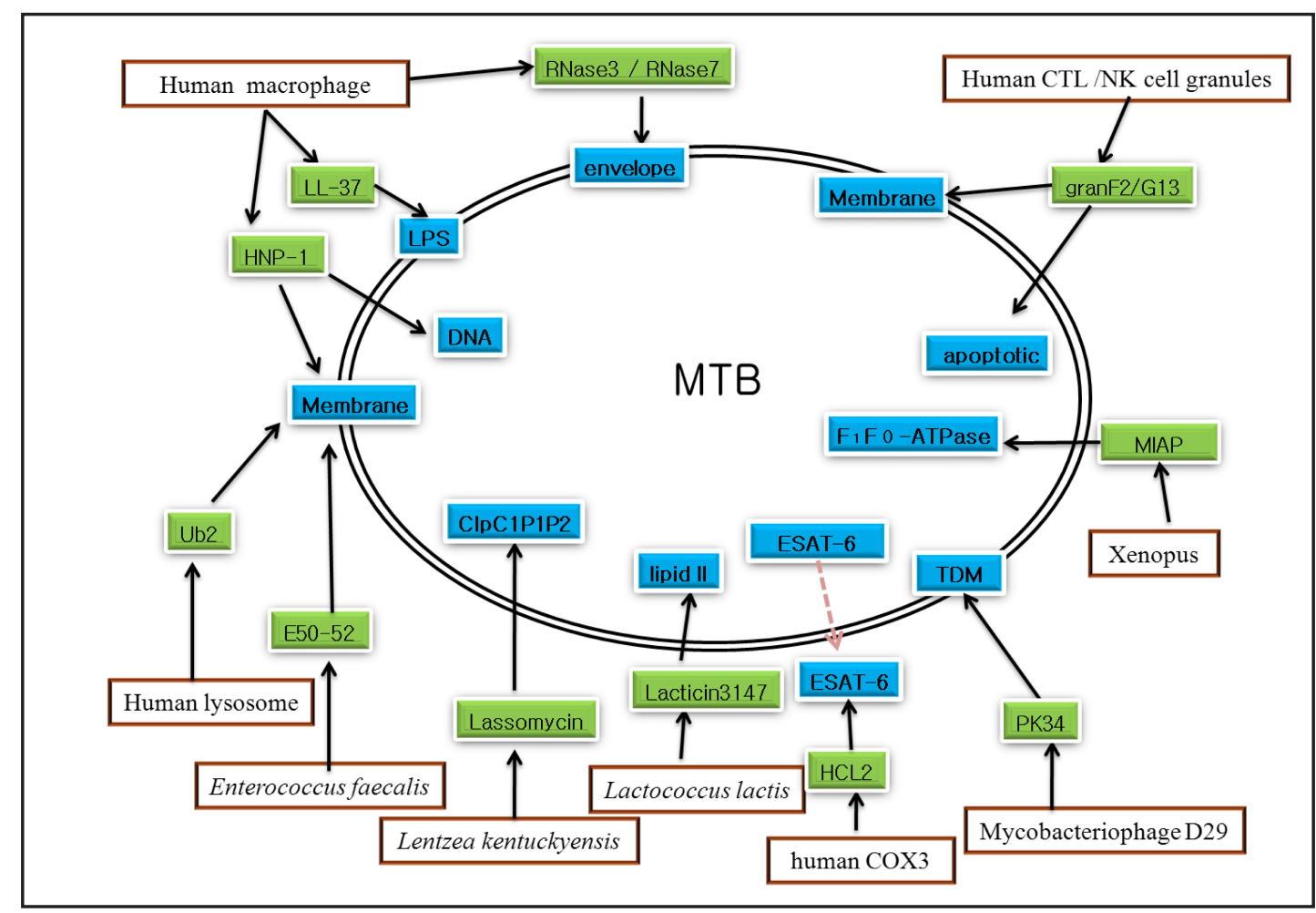

Fig. 1. The targets of anti-mycobacterial peptides

However, it is expected that there are still some obstacles to overcome before developing any of them into a therapeutic drug. A major challenge is that these peptides have a short half-life in vivo and may lose activity in physiological conditions. Secondly, these peptides have a larger size than traditional antibiotics, and how to deliver them and use them to clear intracellular mycobacteria infections would need special attentions. However, several recent studies have shown promising results. Liposomal vectors could be used to enhance these peptides intracellular delivery, reduce immunogenicity, and confer some protection from neutralizing antibodies [80].Thirdly, the attributes of charge, hydrophobicity, saltresistance, biocompatibility, as well as the resistance to antimicrobial peptides (AMPs) [81, 82], may hinder AMPs into clinical applications. For maximum efficacy in vivo and in vitro, these attributes would need optimizing for an antimicrobial peptide. Some strategies have been used to generate peptides with improved antimicrobial activity, such as site-saturation mutagenesis [83], D-amino acids isomerization [84], synthetic modifications [85-87], De novo-design AMPs [87-89] and high-throughput screening [90,91]. These methods provide excellent ways for searching novel and efficient anti-mycobacterial peptides.

Another direction might be using anti-mycobacterial peptides as adjunct chemotherapy with conventional drugs against TB [92]. Combination of conventional anti-mycobacterial drugs with anti-mycobacterial peptides has been found able to prevent drug-resistance and enhance bactericidal action [93-95]. In combination with gold [96] or silver [97] nanoparticles, anti-mycobacterial peptides were enhanced to kill mycobacteria without harming the host cells. Other combinations have also be tried to develop more selective and/ or more potent agents against antibiotics-resistant pathogens. One example was conjugating AMPs to antibiotics like vancomycin using click chemistry [98-100]. Another example was fusing the binding domain of FyuA, which is an outer membrane transporter protein of Yersinia pestis, to the N-terminus of T4 lysozyme similar to pesticin[101, 102]. Further understanding the mechanisms of action, toxicity and immunogenicity of the combinations will help to develop anti-TB drugs based on anti-mycobacterial peptides. 
Teng/Liu/Wei: Anti-Mycobacterial Peptides

\section{Acknowledgement}

We would like to thank the financial supports from the Chinese Academy of Sciences (grant No.: KJZD-EW-L02), Hubei Province's outstanding medical academic leader program (to Jiafa Liu), and the infectious diseases Mega-project of Ministry of Health, China (2009ZXI0003-019).

\section{Reference}

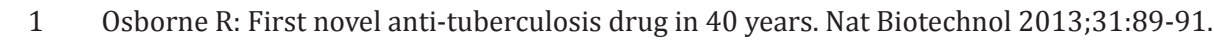

2 Waghu FH, Gopi L, Barai RS, Ramteke P, Nizami B, Idicula-Thomas S: Camp: Collection of sequences and structures of antimicrobial peptides. Nucleic Acids Res 2014;42:D1154-1158.

3 Zhao X, Wu H, Lu H, Li G, Huang Q: Lamp: A database linking antimicrobial peptides. PLoS One 2013;8:e66557.

4 Mendez-Samperio P: The human cathelicidin hcap18/ll-37: A multifunctional peptide involved in mycobacterial infections. Peptides 2010;31:1791-1798.

-5 Sorensen 0, Cowland JB, Askaa J, Borregaard N: An elisa for hcap-18, the cathelicidin present in human neutrophils and plasma. J Immunol Methods 1997;206:53-59.

6 Sorensen OE, Follin P, Johnsen AH, Calafat J, Tjabringa GS, Hiemstra PS, Borregaard N: Human cathelicidin, hcap-18, is processed to the antimicrobial peptide ll-37 by extracellular cleavage with proteinase 3. Blood 2001;97:3951-3959.

7 Liu PT, Stenger S, Tang DH, Modlin RL: Cutting edge: Vitamin d-mediated human antimicrobial activity against mycobacterium tuberculosis is dependent on the induction of cathelicidin. J Immunol 2007;179:2060-2063.

-8 Sonawane A, Santos JC, Mishra BB, Jena P, Progida C, Sorensen OE, Gallo R, Appelberg R, Griffiths G: Cathelicidin is involved in the intracellular killing of mycobacteria in macrophages. Cell Microbiol 2011;13:1601-1617.

-9 Martineau AR, Wilkinson KA, Newton SM, Floto RA, Norman AW, Skolimowska K, Davidson RN, Sorensen OE, Kampmann B, Griffiths CJ, Wilkinson RJ: Ifn-gamma- and tnf-independent vitamin d-inducible human suppression of mycobacteria: The role of cathelicidin ll-37. J Immunol 2007;178:7190-7198.

10 Yamshchikov AV, Kurbatova EV, Kumari M, Blumberg HM, Ziegler TR, Ray SM, Tangpricha V: Vitamin d status and antimicrobial peptide cathelicidin (ll-37) concentrations in patients with active pulmonary tuberculosis. Am J Clin Nutr 2010;92:603-611.

11 Gorr SU, Abdolhosseini M: Antimicrobial peptides and periodontal disease. J Clin Periodontol 2011;38:S126-141.

12 Jiang Z, Higgins MP, Whitehurst J, Kisich KO, Voskuil MI, Hodges RS: Anti-tuberculosis activity of alphahelical antimicrobial peptides: De novo designed l-and d-enantiomers versus l- and d-ll-37. Protein Pept Lett 2011;18:241-252.

13 Nagaoka I, Hirota S, Niyonsaba F, Hirata M, Adachi Y, Tamura H, Tanaka S, Heumann D: Augmentation of the lipopolysaccharide-neutralizing activities of human cathelicidin cap18/ll-37-derived antimicrobial peptides by replacement with hydrophobic and cationic amino acid residues. Clin Diagn Lab Immunol 2002;9:972-982.

14 Mohanty S, Jena P, Mehta R, Pati R, Banerjee B, Patil S, Sonawane A: Cationic antimicrobial peptides and biogenic silver nanoparticles kill mycobacteria without eliciting DNA damage and cytotoxicity in mouse macrophages. Antimicrob Agents Ch 2013;57:3688-3698.

15 McGrath DM, Barbu EM, Driessen WH, Lasco TM, Tarrand JJ, Okhuysen PC, Kontoyiannis DP, Sidman RL, Pasqualini R, Arap W: Mechanism of action and initial evaluation of a membrane active all-d-enantiomer antimicrobial peptidomimetic. Proc Natl Acad Sci U S A 2013;110:3477-3482.

16 Carmona G, Rodriguez A, Juarez D, Corzo G, Villegas E: Improved protease stability of the antimicrobial peptide pin2 substituted with d-amino acids. Protein J 2013;32:456-466.

17 Kolodkin-Gal I, Romero D, Cao S, Clardy J, Kolter R, Losick R: D-amino acids trigger biofilm disassembly. Science 2010;328:627-629.

18 Vandamme D, Landuyt B, Luyten W, Schoofs L: A comprehensive summary of ll-37, the factotum human cathelicidin peptide. Cell Immunol 2012;280:22-35. 
Teng/Liu/Wei: Anti-Mycobacterial Peptides

19 Kurosaka K, Chen Q, Yarovinsky F, Oppenheim JJ, Yang D: Mouse cathelin-related antimicrobial peptide chemoattracts leukocytes using formyl peptide receptor-like 1 /mouse formyl peptide receptor-like 2 as the receptor and acts as immune adjuvant. J Immunol 2005;174:6257-6265.

20 Cho J, Hwang IS, Choi H, Hwang JH, Hwang JS, Lee DG: The novel biological action of antimicrobial peptides via apoptosis induction. J Microbiol Biotechnol 2012;22:1457-1466.

-21 Buchau AS, Morizane S, Trowbridge J, Schauber J, Kotol P, Bui JD, Gallo RL: The host defense peptide cathelicidin is required for nk cell-mediated suppression of tumor growth. J Immunol 2010;184:369-378.

-22 Liu PT, Modlin RL: Human macrophage host defense against mycobacterium tuberculosis. Curr Opin Immunol 2008;20:371-376.

23 Kalita A, Verma I, Khuller GK: Role of human neutrophil peptide-1 as a possible adjunct to antituberculosis chemotherapy. J Infect Dis 2004;190:1476-1480.

24 Sharma S, Verma I, Khuller GK: Therapeutic potential of human neutrophil peptide 1 against experimental tuberculosis. Antimicrob Agents Ch 2001;45:639-640.

25 Sharma S, Khuller GK: DNA as the intracellular secondary target for antibacterial action of human neutrophil peptide-i against mycobacterium tuberculosis h37ra. Curr Microbiol 2001;43:74-76.

26 Sharma S, Verma I, Khuller GK: Biochemical interaction of human neutrophil peptide-1 with mycobacterium tuberculosis h37ra. Arch Microbiol 1999;171:338-342.

-27 Sharma S, Verma I, Khuller GK: Antibacterial activity of human neutrophil peptide-1 against mycobacterium tuberculosis h37rv: In vitro and ex vivo study. EurRespir J 2000;16:112-117.

28 Zhu LM, Liu CH, Chen P, Dai AG, Li CX, Xiao K, Chen Y, Cao J, Chen YR: Multidrug-resistant tuberculosis is associated with low plasma concentrations of human neutrophil peptides 1-3. Int J Tuberc Lung D 2011;15:369-374.

29 Pazgier M, Hoover DM, Yang D, Lu W, Lubkowski J: Human beta-defensins. Cell Mol Life Sci 2006;63:12941313.

-30 Gonzalez-Curiel I, Castaneda-Delgado J, Lopez-Lopez N, Araujo Z, Hernandez-Pando R, Gandara-Jasso B, Macias-Segura N, Enciso-Moreno A, Rivas-Santiago B: Differential expression of antimicrobial peptides in active and latent tuberculosis and its relationship with diabetes mellitus. Hum Immunol 2011;72:656-662.

-31 Kisich KO, Heifets L, Higgins M, Diamond G: Antimycobacterial agent based on mrna encoding human betadefensin 2 enables primary macrophages to restrict growth of mycobacterium tuberculosis. Infect Immun 2001;69:2692-2699.

32 Rivas-Santiago CE, Rivas-Santiago B, Leon DA, Castaneda-Delgado J, Pando RH: Induction of betadefensins by l-isoleucine as novel immunotherapy in experimental murine tuberculosis. Clin Exp Immunol 2011;164:80-89.

-33 Rivas-Santiago B, Cervantes-Villagrana A, Sada E, Hernandez-Pando R: Expression of beta defensin 2 in experimental pulmonary tuberculosis: Tentative approach for vaccine development. Arch Med Res 2012;43:324-328.

-34 Mendez-Samperio P: Recent advances in the field of antimicrobial peptides in inflammatory diseases. Adv Biomed Res 2013;2:50.

-35 Ernst CM, Peschel A: Broad-spectrum antimicrobial peptide resistance by mprf-mediated aminoacylation and flipping of phospholipids. Mol Microbiol 2011;80:290-299.

-36 Pitabut N, Sakurada S, Tanaka T, Ridruechai C, Tanuma J, Aoki T, Kantipong P, Piyaworawong S, Kobayashi N, Dhepakson P, Yanai H, Yamada N, Oka S, Okada M, Khusmith S, Keicho N: Potential function of granulysin, other related effector molecules and lymphocyte subsets in patients with tb and hiv/tb coinfection. Int J Med Sci 2013;10:1003-1014.

37 Stenger S, Hanson DA, Teitelbaum R, Dewan P, Niazi KR, Froelich CJ, Ganz T, Thoma-Uszynski S, Melian A, Bogdan C, Porcelli SA, Bloom BR, Krensky AM, Modlin RL: An antimicrobial activity of cytolytic t cells mediated by granulysin. Science 1998;282:121-125.

-38 Okada M, Kita Y, Nakajima T, Kanamaru N, Hashimoto S, Nagasawa T, Kaneda Y, Yoshida S, Nishida Y, Nakatani H, Takao K, Kishigami C, Nishimatsu S, Sekine Y, Inoue Y, Matsumoto M, McMurray DN, De la Cruz EC, Tan EV, Abalos RM, Burgos JA, Saunderson P, Sakatani M: Novel therapeutic vaccine: Granulysin and new DNA vaccine against tuberculosis. Hum Vaccin 2011; 7:S60-67.

-39 Mueller H, Fae KC, Magdorf K, Ganoza CA, Wahn U, Guhlich U, Feiterna-Sperling C, Kaufmann SHE: Granulysin-expressing cd4(+) t cells as candidate immune marker for tuberculosis during childhood and adolescence. PLoS One 2011;6:e29367. 
40 Andreu D, Carreno C, Linde C, Boman HG, Andersson M: Identification of an anti-mycobacterial domain in nk-lysin and granulysin. Biochem J 1999;344 Pt 3:845-849.

41 Wang Z, Choice E, Kaspar A, Hanson D, Okada S, Lyu SC, Krensky AM, Clayberger C: Bactericidal and tumoricidal activities of synthetic peptides derived from granulysin. J Immunol 2000;165:1486-1490.

42 Toro JC, Hoffner S, Linde C, Andersson M, Andersson J, Grundstrom S: Enhanced susceptibility of multidrug resistant strains of mycobacterium tuberculosis to granulysin peptides correlates with a reduced fitness phenotype. Microbes Infect 2006;8:1985-1993.

43 Purdy GE, Russell DG: Lysosomal ubiquitin and the demise of mycobacterium tuberculosis. Cell Microbiol 2007;9:2768-2774.

44 Alonso S, Pethe K, Russell DG, Purdy GE: Lysosomal killing of mycobacterium mediated by ubiquitinderived peptides is enhanced by autophagy. P Natl Acad Sci USA 2007;104:6031-6036.

45 Wang QM, Kang L, Wang XH: Improved cellular immune response elicited by a ubiquitin-fused esat-6 DNA vaccine against mycobacterium tuberculosis. Microbiol Immunol 2009;53:384-390.

46 Wang QM, Tang Y, Lei Ch X, Shi FZ, Liu QH: Enhanced cellular immune response elicited by a DNA vaccine fused with ub against mycobacterium tuberculosis. Scand J Immunol 2012;76:123-130.

47 Wang Q, Lei C, Wan H, Liu Q: Improved cellular immune response elicited by a ubiquitin-fused DNA vaccine against mycobacterium tuberculosis. DNA Cell Biol 2012;31:489-495.

-48 Kieffer AE, Goumon Y, Ruh 0, Chasserot-Golaz S, Nullans G, Gasnier C, Aunis D, Metz-Boutigue MH: The nand c-terminal fragments of ubiquitin are important for the antimicrobial activities. FASEB J 2003;17:776778.

49 Foss MH, Powers KM, Purdy GE: Structural and functional characterization of mycobactericidal ubiquitinderived peptides in model and bacterial membranes. Biochemistry 2012;51:9922-9929.

50 Purdy GE, Niederweis M, Russell DG: Decreased outer membrane permeability protects mycobacteria from killing by ubiquitin-derived peptides. Mol Microbiol 2009;73:844-857.

51 Daugherty A, Powers KM, Standley MS, Kim CS, Purdy GE: Mycobacterium smegmatis roxy is a repressor of oxys and contributes to resistance to oxidative stress and bactericidal ubiquitin-derived peptides. J Bacteriol 2011;193:6824-6833.

52 Nemeth E, Tuttle MS, Powelson J, Vaughn MB, Donovan A, Ward DM, Ganz T, Kaplan J: Hepcidin regulates cellular iron efflux by binding to ferroportin and inducing its internalization. Science 2004;306:2090-2093.

53 Nicolas G, Chauvet C, Viatte L, Danan JL, Bigard X, Devaux I, Beaumont C, Kahn A, Vaulont S: The gene encoding the iron regulatory peptide hepcidin is regulated by anemia, hypoxia, and inflammation. J Clin Invest 2002;110:1037-1044.

54 Sow FB, Florence WC, Satoskar AR, Schlesinger LS, Zwilling BS, Lafuse WP: Expression and localization of hepcidin in macrophages: A role in host defense against tuberculosis. J Leukoc Biol 2007;82:934-945.

55 Sow FB, Nandakumar S, Velu V, Kellar KL, Schlesinger LS, Amara RR, Lafuse WP, Shinnick TM, Sable SB: Mycobacterium tuberculosis components stimulate production of the antimicrobial peptide hepcidin. Tuberculosis (Edinb) 2011;91:314-321.

56 Layoun A, Santos MM: Bacterial cell wall constituents induce hepcidin expression in macrophages through myd88 signaling. Inflammation 2012;35:1500-1506.

57 Pulido D, Torrent M, Andreu D, Nogues MV, Boix E: Two human host defense ribonucleases against mycobacteria, the eosinophil cationic protein (rnase 3) and rnase 7. Antimicrob Agents Chemother 2013;57:3797-3805.

58 Yang H, Chen HZ, Liu ZH, Ma H, Qin LH, Jin RL, Zheng RJ, Feng YH, Cui ZL, Wang J, Liu JM, Hu ZY: A novel b-cell epitope identified within mycobacterium tuberculosis cfp $10 /$ esat- 6 protein. PLoS One 2013;8:e52848.

-59 Meher AK, Bal NC, Chary KV, Arora A: Mycobacterium tuberculosis h37rv esat-6-cfp-10 complex formation confers thermodynamic and biochemical stability. FEBS J 2006;273:1445-1462.

-60 Chatterjee S, Dwivedi VP, Singh Y, Siddiqui I, Sharma P, Van Kaer L, Chattopadhyay D, Das G: Early secreted antigen esat- 6 of mycobacterium tuberculosis promotes protective thelper 17 cell responses in a toll-like receptor-2-dependent manner. PLoS Pathog 2011;7:e1002378.

61 Cotter PD, Hill C, Ross RP: Bacterial lantibiotics: Strategies to improve therapeutic potential. Curr Protein Pept Sci 2005;6:61-75.

-62 Carroll J, Draper LA, O'Connor PM, Coffey A, Hill C, Ross RP, Cotter PD, O'Mahony J: Comparison of the activities of the lantibiotics nisin and lacticin 3147 against clinically significant mycobacteria. Int J Antimicrob Agents 2010;36:132-136. 
Teng/Liu/Wei: Anti-Mycobacterial Peptides

63 Morgan SM, O'Connor P M, Cotter PD, Ross RP, Hill C: Sequential actions of the two component peptides of the lantibiotic lacticin 3147 explain its antimicrobial activity at nanomolar concentrations. Antimicrob Agents Chemother 2005;49:2606-2611.

64 Draper LA, Cotter PD, Hill C, Ross RP: The two peptide lantibiotic lacticin 3147 acts synergistically with polymyxin to inhibit gram negative bacteria. BMC Microbiol 2013;13:212.

65 Cotter PD, O'Connor PM, Draper LA, Lawton EM, Deegan LH, Hill C, Ross RP: Posttranslational conversion of l-serines to d-alanines is vital for optimal production and activity of the lantibiotic lacticin 3147. Proc Natl Acad Sci U S A 2005;102:18584-18589.

66 Suda S, Lawton EM, Wistuba D, Cotter PD, Hill C, Ross RP: Homologues and bioengineered derivatives of ltnj vary in ability to form d-alanine in the lantibiotic lacticin 3147. J Bacteriol 2012;194:708-714.

67 Islam MR, Nagao J, Zendo T, Sonomoto K: Antimicrobial mechanism of lantibiotics. Biochem Soc Trans 2012;40:1528-1533.

68 Asaduzzaman SM, Sonomoto K: Lantibiotics: Diverse activities and unique modes of action. J Biosci Bioeng 2009;107:475-487.

69 Martin NI, Breukink E: Expanding role of lipid ii as a target for lantibiotics. Future Microbiol 2007;2:513525.

70 Draper LA, Grainger K, Deegan LH, Cotter PD, Hill C, Ross RP: Cross-immunity and immune mimicry as mechanisms of resistance to the lantibiotic lacticin 3147. Mol Microbiol 2009;71:1043-1054.

71 Sosunov V, Mischenko V, Eruslanov B, Svetoch E, Shakina Y, Stern N, Majorov K, Sorokoumova G, Selishcheva A, Apt A: Antimycobacterial activity of bacteriocins and their complexes with liposomes. J Antimicrob Chemoth 2007;59:919-925.

72 Gavrish E, Sit CS, Cao SG, Kandror O, Spoering A, Peoples A, Ling L, Fetterman A, Hughes D, Bissell A, Torrey H, Akopian T, Mueller A, Epstein S, Goldberg A, Clardy J, Lewis K: Lassomycin, a ribosomally synthesized cyclic peptide, kills mycobacterium tuberculosis by targeting the atp-dependent protease clpc1p1p2. Chem Biol 2014;21:509-518.

73 Akopian T, Kandror O, Raju RM, UnniKrishnan M, Rubin EJ, Goldberg AL: The active clpp protease from m. Tuberculosis is a complex composed of a heptameric clpp1 and a clpp2 ring. Embo J 2012;31:1529-1541.

74 Sassi M, Bebeacua C, Drancourt M, Cambillau C: The first structure of a mycobacteriophage, the mycobacterium abscessus subsp. Bolletii phage araucaria. J Virol 2013;87:8099-8109.

75 Wei L, Wu J, Liu H, Yang HL, Rong MQ Li DS, Zhang PH, Han JY, Lai R: A mycobacteriophage-derived trehalose-6,6 '-dimycolate-binding peptide containing both antimycobacterial and anti-inflammatory abilities. Faseb J 2013;27:3067-3077.

76 Fenton M, Keary R, McAuliffe 0, Ross RP, O'Mahony J, Coffey A: Bacteriophage-derived peptidase chap(k) eliminates and prevents staphylococcal biofilms. Int J Microbiol 2013;2013:625341.

77 Horgan M, O'Flynn G, Garry J, Cooney J, Coffey A, Fitzgerald GF, Ross RP, McAuliffe O: Phage lysin lysk can be truncated to its chap domain and retain lytic activity against live antibiotic-resistant staphylococci. Appl Environ Microb 2009;75:872-874.

78 Yang H, Wang DB, Dong Q, Zhang Z, Cui Z, Deng J, Yu J, Zhang XE, Wei H: Existence of separate domains in lysin plyg for recognizing bacillus anthracis spores and vegetative cells. Antimicrob Agents Chemother 2012;56:5031-5039.

79 Loessner MJ: Bacteriophage endolysins--current state of research and applications. Curr Opin Microbiol 2005;8:480-487.

-80 Wan Y, Han J, Fan G, Zhang Z, Gong T, Sun X: Enzyme-responsive liposomes modified adenoviral vectors for enhanced tumor cell transduction and reduced immunogenicity. Biomaterials 2013;34:3020-3030.

81 Lofton H, Pranting M, Thulin E, Andersson DI: Mechanisms and fitness costs of resistance to antimicrobial peptides ll-37, cny100hl and wheat germ histones. PLoS One 2013;8:e68875.

82 Ryan L, Lamarre B, Diu T, Ravi J, Judge PJ, Temple A, Carr M, Cerasoli E, Su B, Jenkinson HF, Martyna G, Crain J, Watts A, Ryadnov MG: Anti-antimicrobial peptides: Folding-mediated host defense antagonists. J Biol Chem 2013;288:20162-20172.

-83 Field D, Begley M, O'Connor PM, Daly KM, Hugenholtz F, Cotter PD, Hill C, Ross RP: Bioengineered nisin a derivatives with enhanced activity against both gram positive and gram negative pathogens. PLoS One 2012;7.

84 Falciani C, Lozzi L, Pollini S, Luca V, Carnicelli V, Brunetti J, Lelli B, Bindi S, Scali S, Di Giulio A, Rossolini GM, Mangoni ML, Bracci L, Pini A: Isomerization of an antimicrobial peptide broadens antimicrobial spectrum to gram-positive bacterial pathogens. PLoS One 2012;7. 
Teng/Liu/Wei: Anti-Mycobacterial Peptides

85 Wang Y, Ke XY, Khara JS, Bahety P, Liu SQ, Seow SV, Yang YY, Ee PLR: Synthetic modifications of the immunomodulating peptide thymopentin to confer anti-mycobacterial activity. Biomaterials 2014;35:3102-3109.

86 Munk JK, Ritz C, Fliedner FP, Frimodt-Moller N, Hansen PR: Novel method to identify the optimal antimicrobial peptide in a combination matrix, using anoplin as an example. Antimicrob Agents Chemother 2014;58:1063-1070.

-87 Saravanan R, Li X, Lim K, Mohanram H, Peng L, Mishra B, Basu A, Lee JM, Bhattacharjya S, Leong SS: Design of short membrane selective antimicrobial peptides containing tryptophan and arginine residues for improved activity, salt-resistance, and biocompatibility. Biotechnol Bioeng 2014;111:37-49.

-88 Dangel A, Ackermann N, Abdel-Hadi O, Maier R, Onder K, Francois P, Muller CW, Pane-Farre J, Engelmann S, Schrenzel J, Heesemann J, Lindermayr C: A de novo-designed antimicrobial peptide with activity against multiresistant staphylococcus aureus acting on rsbw kinase. FASEB J 2013;27:4476-4488.

89 Mooney C, Haslam NJ, Pollastri G, Shields DC: Towards the improved discovery and design of functional peptides: Common features of diverse classes permit generalized prediction of bioactivity. PLoS One 2012; 7:e45012.

-90 Hilpert K, Volkmer-Engert R, Walter T, Hancock REW: High-throughput generation of small antibacterial peptides with improved activity. Nat Biotechnol 2005;23:1008-1012.

-91 Guralp SA, Murgha YE, Rouillard JM, Gulari E: From design to screening: A new antimicrobial peptide discovery pipeline. PLoS One 2013;8:e59305.

92 Hassan M, Kjos M, Nes IF, Diep DB, Lotfipour F: Natural antimicrobial peptides from bacteria: Characteristics and potential applications to fight against antibiotic resistance. J Appl Microbiol 2012;113:723-736.

93 Yan JX, Wang KR, Dang W, Chen R, Xie JQ, Zhang BZ, Song JJ, Wang R: Two hits are better than one: Membrane-active and DNA binding-related double-action mechanism of nk-18, a novel antimicrobial peptide derived from mammalian nk-lysin. Antimicrob Agents Ch 2013;57:220-228.

$\$ 94$ Devocelle M: Targeted antimicrobial peptides. Front Immunol 2012;3:309.

-95 Li Y, Xiang Q, Zhang Q, Huang Y, Su Z: Overview on the recent study of antimicrobial peptides: Origins, functions, relative mechanisms and application. Peptides 2012;37:207-215.

-96 Zhao YY, Tian Y, Cui Y, Liu WW, Ma WS, Jiang XY: Small molecule-capped gold nanoparticles as potent antibacterial agents that target gram-negative bacteria. J Am Chem Soc 2010;132:12349-12356.

97 Mohanty S, Jena P, Mehta R, Pati R, Banerjee B, Patil S, Sonawane A: Cationic antimicrobial peptides and biogenic silver nanoparticles kill mycobacteria without eliciting DNA damage and cytotoxicity in mouse macrophages. Antimicrob Agents Chemother 2013;57:3688-3698.

$\$ 98$ Arnusch CJ, Pieters RJ, Breukink E: Enhanced membrane pore formation through high-affinity targeted antimicrobial peptides. PLoS One 2012;7.

-99 Filatova LY, Donovan DM, Becker SC, Lebedev DN, Priyma AD, Koudriachova HV, Kabanov AV, Klyachko NL: Physicochemical characterization of the staphylolytic lysk enzyme in complexes with polycationic polymers as a potent antimicrobial. Biochimie 2013;95:1689-1696.

100 Joshi S, Bisht GS, Rawat DS, Maiti S, Pasha S: Comparative mode of action of novel hybrid peptide cs-1a and its rearranged amphipathic analogue cs-2a. FEBS J 2012;279:3776-3790.

101 Lukacik P, Barnard TJ, Keller PW, Chaturvedi KS, Seddiki N, Fairman J, Noinaj N, Kirby TL, Henderson JP, Steven AC, Hinnebusch BJ, Buchanan SK: Structural engineering of a phage lysin that targets gram-negative pathogens. P Natl Acad Sci USA 2012;109:9857-9862.

102 Patzer SI, Albrecht R, Braun V, Zeth K: Structural and mechanistic studies of pesticin, a bacterial homolog of phage lysozymes. J Biol Chem 2012;287:23381-23396.

103 Singh D, Qi RS, Jordan JL, Mateo LS, Kao CC: The human antimicrobial peptide ll-37, but not the mouse ortholog, mcramp, can stimulate signaling by poly(i:C) through a fprl1-dependent pathway. J Biol Chem 2013;288:8258-8268.

104 Llamas-Gonzalez YY, Pedroza-Roldan C, Cortes-Serna MB, Marquez-Aguirre AL, Galvez-Gastelum FJ, FloresValdez MA: The synthetic cathelicidin hhc-10 inhibits mycobacterium bovis bcg in vitro and in c57bl/6 mice. Microb Drug Resist 2013;19:124-129.

105 Yamshchikov AV, Kurbatova EV, Kumari M, Blumberg HM, Ziegler TR, Ray SM, Tangpricha V: Vitamin d status and antimicrobial peptide cathelicidin (ll-37) concentrations in patients with active pulmonary tuberculosis. Am J Clin Nutr 2010;92:603-611. 
Teng/Liu/Wei: Anti-Mycobacterial Peptides

106 Martineau AR, Wilkinson KA, Newton SM, Floto RA, Norman AW, Skolimowska K, Davidson RN, Sorensen OE, Kampmann B, Griffiths CJ, Wilkinson RJ: Ifn-gamma- and tnf-independent vitamin d-inducible human suppression of mycobacteria: The role of cathelicidin ll-37 (vol 178, pg 7190, 2007). J Immunol 2007;179:8569-8570.

107 Rivas-Santiago B, Rivas Santiago CE, Castaneda-Delgado JE, Leon-Contreras JC, Hancock RE, HernandezPando R: Activity of ll-37, cramp and antimicrobial peptide-derived compounds e2, e6 and cp26 against mycobacterium tuberculosis. Int J Antimicrob Agents 2013;41:143-148.

108 Rivas-Santiago B, Hernandez-Pando R, Carranza C, Juarez E, Contreras JL, Aguilar-Leon D, Torres M, Sada E: Expression of cathelicidin ll-37 during mycobacterium tuberculosis infection in human alveolar macrophages, monocytes, neutrophils, and epithelial cells. Infect Immun 2008;76:935-941.

109 Mohanty S, Jena P, Mehta R, Pati R, Banerjee B, Patil S, Sonawane A: Cationic antimicrobial peptides and biogenic silver nanoparticles kill mycobacteria without eliciting DNA damage and cytotoxicity in mouse macrophages. Antimicrob Agents Chemother 2013;57:3688-3698.

110 Yacoby I, Benhar I: Targeted anti bacterial therapy. Infect Disord Drug Targets 2007;7:221-229.

111 Schneider JJ, Unholzer A, Schaller M, Schafer-Korting M, Korting HC: Human defensins. J Mol Med (Berl) 2005;83:587-595.

112 Samuchiwal SK, Tousif S, Singh DK, Kumar A, Ghosh A, Bhalla K, Prakash P, Kumar S, Bhattacharyya M, Moodley P, Das G, Ranganathan A: A peptide fragment from the human cox3 protein disrupts association of mycobacterium tuberculosis virulence proteins esat- 6 and cfp 10 , inhibits mycobacterial growth and mounts protective immune response. BMC Infect Dis 2014;14:355.

113 Santos P, Gordillo A, Osses L, Salazar LM, Soto CY: Effect of antimicrobial peptides on atpase activity and proton pumping in plasma membrane vesicles obtained from mycobacteria. Peptides 2012;36:121-128.

114 Duclohier H, Molle G, Spach G: Antimicrobial peptide magainin-i from xenopus skin forms anion-permeable channels in planar lipid bilayers. Biophys J 1989;56:1017-1021.

115 Kieffer AE, Goumon Y, Ruh O, Chasserot-Golaz S, Nullans G, Gasnier C, Aunis D, Metz-Boutigue MH: The nand c-terminal fragments of ubiquitin are important for the antimicrobial activities. Faseb J 2003;17:776778.

116 Spencer JD, Schwaderer AL, DiRosario JD, McHugh KM, McGillivary G, Justice SS, Carpenter AR, Baker PB, Harder J, Hains DS: Ribonuclease 7 is a potent antimicrobial peptide within the human urinary tract. Kidney Int 2011;80:175-181.

117 Sow FB, Alvarez GR, Gross RP, Satoskar AR, Schlesinger LS, Zwilling BS, Lafuse WP: Role of stat1, nf-kappa $\mathrm{b}$, and $\mathrm{c} / \mathrm{ebp}$ beta in the macrophage transcriptional regulation of hepcidin by mycobacterial infection and ifn-gamma. J Leukocyte Biol 2009;86:1247-1258.

118 Barthe C, Hocquellet A, Garbay B: Bacteriostatic activity of the proregion of human hepcidin. Protein Pept Lett 2011;18:36-40.

119 Silva T, Magalhaes B, Maia S, Gomes P, Nazmi K, Bolscher JG, Rodrigues PN, Bastos M, Gomes MS: Killing of mycobacterium avium by lactoferricin peptides: Improved activity of arginine- and d-amino-acidcontaining molecules. Antimicrob Agents Chemother 2014;58:3461-3467.

120 Carroll J, Field D, O'Connor PM, Cotter PD, Coffey A, Hill C, Ross RP, O'Mahony J: Gene encoded antimicrobial peptides, a template for the design of novel anti-mycobacterial drugs. Bioeng Bugs 2010;1:408-412.

121 Morgan SM, O'Connor PM, Cotter PD, Ross RP, Hill C: Sequential actions of the two component peptides of the lantibiotic lacticin 3147 explain its antimicrobial activity at nanomolar concentrations. Antimicrob Agents Ch 2005;49:2606-2611.

122 Ryan MP, Jack RW, Josten M, Sahl HG, Jung G, Ross RP, Hill C: Extensive post-translational modification, including serine to d-alanine conversion, in the two-component lantibiotic, lacticin 3147. J Biol Chem 1999;274:37544-37550.

123 Kapoor R, Eimerman PR, Hardy JW, Cirillo JD, Contag CH, Barron AE: Efficacy of antimicrobial peptoids against mycobacterium tuberculosis. Antimicrob Agents Ch 2011;55:3058-3062.

124 Jena P, Mishra B, Leippe M, Hasilik A, Griffiths G, Sonawane A: Membrane-active antimicrobial peptides and human placental lysosomal extracts are highly active against mycobacteria. Peptides 2011;32:881-887. 